\title{
THE POTENTIAL OF WILD SUNFLOWER SPECIES FOR INDUSTRIAL USES
}

\author{
Seiler, G.J.*
}

Northern Crop Science Laboratory, U.S. Department of Agriculture, Agricultural Research Service, P.O. Box 5677, Fargo, ND 58105, USA

Received: October 10, 2006 Accepted: May 15, 2007

\section{SUMMARY}

Within the past decade, the desire for alternative sources of fuels, chemicals, feeds, and other materials has received increased attention. Wild sunflower species have the potential to contribute to these renewable resources. During the past three decades, the narrow genetic base of cultivated sunflower has been broadened by the infusion of genes from wild relatives, which have provided a continuous source of agronomic traits for crop improvement. The genus Helianthus is composed of 51 species and 19 subspecies with 14 annual and 37 perennial species. Although oil concentrations of up to $37 \mathrm{~g} / \mathrm{kg}$ have been reported in whole plants of one wild sunflower species, H. ciliaris, the achenes are the primary storage tissue for oil. The fatty acid composition of the achene oil determines its suitability for either food or industrial uses. Considerable variability has been reported in fatty acid composition of oil in achenes of the wild species. Other natural products may also be of economic value from the wild sunflower species. A natural rubber concentration of $19 \mathrm{~g} / \mathrm{kg}$ has been reported in the whole plant of wild perennial $H$. radula with more than $92 \%$ pure rubber. Polyphenol yields of wild sunflower biomass are moderate, with $H$. strumosus yielding $139 \mathrm{~g} / \mathrm{kg}$. Hydrocarbon yields for wild sunflower biomass are average for most species, with $H$. salicifolius having the highest yield of $16 \mathrm{~g} / \mathrm{kg}$. The sugars in the stalks and tubers of Jerusalem artichoke $(H$. tuberosus) have been suggested as a potential source for bioethanol production. Jerusalem artichoke has been evaluated for inulin and sugar yield from stalks, yielding 10.4 and $8.0 \mathrm{t} / \mathrm{ha}$, respectively, while tubers yield $13.7 \mathrm{t} / \mathrm{ha}$ of inulin and $13.3 \mathrm{t} / \mathrm{ha}$ of fructose. Biomass production has also been investigated in Jerusalem artichoke. Dry matter forage yields of 3.0 to $9.9 \mathrm{t} / \mathrm{ha}$ and tuber yields of 2.8 to 12.8 t/ha have been reported. Further research will be needed to assess the potential use of wild species for industrial purposes through selection and breeding.

Key words: sunflower, wild species, alternative sources of fuels, renewable resources, natural rubber, polyphenol, bioethanol

\footnotetext{
* Corresponding author: e-mail: seilerg@fargo.ars.usda.gov
} 


\section{INTRODUCTION}

Within the last decade, the identification and cultivation of plants rich in hydrocarbons as renewable sources of chemicals for use as fuel and chemical feedstocks have generated considerable interest. The worldwide increase in demand and depletion of fossil hydrocarbons warrant development of alternate sources of fuels and chemicals. Renewable sources would not only reduce global dependency on strategic and essential materials, especially petroleum products, but could also stimulate economic growth (Knowles and Lessman, 1984).

The genus Helianthus consists of 51 species and 19 subspecies with 14 annual and 37 perennial species (Schilling and Heiser, 1981). The narrow genetic base of cultivated sunflower has been broadened by the infusion of genes from wild species. This has resulted in continuous improvement of agronomic and economic traits in cultivated sunflower (Thompson et al., 1981; Seiler, 1992; Seiler and Rieseberg, 1997).

In recent years, there has also been considerable interest in developing and utilizing plants adapted to arid and semiarid conditions, particularly for industrial nonfood uses (Davis et al., 1983). Many wild sunflower species inhabit semiarid areas and may be potentially useful as sources of industrial raw materials if additional information were available concerning their chemical composition. Phytochemical studies of the genus Helianthus have led to the identification and isolation of several chemicals. The following discussion covers what is known about the phytochemicals of the wild sunflower species and their potential for industrial uses.

\section{PHYTOCHEMICALS}

Vascular plants produce many primary and secondary metabolites. Energy-rich plant products useful as substitutes, supplements or complements of petrochemicals are now generally called botanochemicals (Buchanan et al., 1980). It is especially attractive from both social and economic viewpoints to consider agricultural systems for integrated production of primary and secondary botanochemicals (Buchanan et al., 1980).

Botanochemicals include substances which can be extracted directly from plants (primary botanochemicals) and those made by conversion of insoluble saccharides or lignocelluloses (secondary or derived botanochemicals). Primary botanochemicals include products such as naval store (pine chemicals), tall-oil products (paper-pulping byproducts), lubricating oils for industrial uses, waxes, tannins, rubber, and gutta. Traditional secondary botanochemicals include furfural and ethanol. Potential new botanochemicals include whole-plant oils, latex, guayule rubber, grass gutta-percha, polyphenols, and specialty seed oils.

The current concern about the availability of petroleum resources from foreign markets has stimulated studies that focus on obtaining energy and industrial products from alternate sources. In agriculture, the emphasis has been on the use of 
agricultural residues as potential sources of energy and on the development of exotic or little-utilized plant species as substitutes for petrochemicals.

\section{Non-polar extractables - cyclohexane}

Non-polar extractable components consist of hydrocarbons and rubber. Fortyeight accessions of wild sunflowers representing 39 taxa were examined for yields of non-polar extractables (hydrocarbons, rubber, etc.) (Adams and Seiler, 1984). Taxa with the highest yields of non-polar material were $H$. agrestis with $73.8 \mathrm{~g} / \mathrm{kg}, H$. annuus from Hinton, Oklahoma, with $70.9 \mathrm{~g} / \mathrm{kg}, H$. argophyllus with $65.2 \mathrm{~g} / \mathrm{kg}, H$. arizonensis with $61.3 \mathrm{~g} / \mathrm{kg}, H$. anomalus with $57.4 \mathrm{~g} / \mathrm{kg}, \mathrm{H}$. ciliaris with $52.6 \mathrm{~g} / \mathrm{kg}$, $H$. nuttallii from Orovada, Nevada with $52.5 \mathrm{~g} / \mathrm{kg}, \mathrm{H}$. praecox subsp. hirtus with $51.9 \mathrm{~g} / \mathrm{kg}$, and $H$. nuttallii from Payson, Utah with $51.7 \mathrm{~g} / \mathrm{kg}$. Of these eight taxa, five are annuals. Since only 11 annual taxa were present in the 39 taxa examined, there does not seem to be a tendency for the annuals to have more cyclohexane non-polar extractables. One of the most interesting comparisons is between wild $H$. annuus with $70.9 \mathrm{~g} / \mathrm{kg}$ and a cultivated $H$. annuus hybrid with $22.3 \mathrm{~g} / \mathrm{kg}$. This suggests that there may be considerable infraspecific variation which could be exploited.

The non-polar cyclohexane values observed for wild sunflower species are comparable to those of several plant species evaluated for phytochemicals. Cyclohexane extractable yields of $47.2 \mathrm{~g} / \mathrm{kg}$ were observed in Asclepias speciosa, $52.0 \mathrm{~g} / \mathrm{kg}$ in Baccharus neglecta, $46.6 \mathrm{~g} / \mathrm{kg}$ in Calotropis procera, $66.1 \mathrm{~g} / \mathrm{kg}$ in Euphorbia lathyris, $63.5 \mathrm{~g} / \mathrm{kg}$ in Rhus glabra, and $73.8 \mathrm{~g} / \mathrm{kg}$ in Grindelia squarrosa (Adams and Seiler, 1984). Non-polar extractable yields greater than $70 \mathrm{~g} / \mathrm{kg}$ are not unusual (Adams and McChesney, 1982).

\section{Polar extractables - methanol}

Polar extractables components are phenolics, sugars, and free amino acids. Forty-eight accessions of wild sunflowers representing 39 taxa were examined for yields of polar extractables (resins, sugars, etc.) (Adams and Seiler, 1984). Methanol extractable botanochemicals ranged from nearly 68.7 to $210 \mathrm{~g} / \mathrm{kg}$. The highest yielding taxa were $H$. petiolaris subsp. petiolaris with $210 \mathrm{~g} / \mathrm{kg}, H$. paradoxus with $195.4 \mathrm{~g} / \mathrm{kg}, \mathrm{H}$. occidentalis subsp. plantagineus with $183.3 \mathrm{~g} / \mathrm{kg}, \mathrm{H}$. laevigatus with $182.4 \mathrm{~g} / \mathrm{kg}, H$. silphioides with $180.1 \mathrm{~g} / \mathrm{kg}$, and $H$. ciliaris with $171.7 \mathrm{~g} / \mathrm{kg}$. In general, those taxa with higher yields are comparable to several promising species previously reported. They include Asclepias speciosa with $186.7 \mathrm{~g} / \mathrm{kg}$, Calotropis procera with $167.8 \mathrm{~g} / \mathrm{kg}$, Euphorbia lathyris with $191.3 \mathrm{~g} / \mathrm{kg}$, Rhus glabra with 462 $\mathrm{g} / \mathrm{kg}$, and Grindelia squarrosa with $105.2 \mathrm{~g} / \mathrm{kg}$. Methanol extractable yields greater than $180 \mathrm{~g} / \mathrm{kg}$ are not unusual (Adams and McChesney, 1982).

\section{Polyphenol}

Polyphenol is generic term referring to a large complex of phytochemicals with hydroxyl-substituted aromatic rings (Buchanan et al., 1980). It includes such 
chemicals as polyphenolics, tannins, flavonoids, lignin fractions, and complex lipids. If large volumes of low-cost plant polyphenols became available, they could become very important chemical feedstocks (Buchanan et al., 1980).

Twenty-eight taxa of Helianthus collected throughout the USA and grown in a field nursery at Bushland, Texas, USA, were analyzed for yields of solvent extractable fractions referred to as polyphenols in aboveground biomass (Seiler et al., 1991). Polyphenol yields observed were moderate, varying from $29 \mathrm{~g} / \mathrm{kg}$ in $H$. pumilus to $139 \mathrm{~g} / \mathrm{kg}$ in $H$. strumosus. A polyphenol yield of $200 \mathrm{~g} / \mathrm{kg}$ is considered high (Carr and Bagby, 1987). All but one of the wild sunflowers (H. strumosus) yielded less than $100 \mathrm{~g} / \mathrm{kg}$ of polyphenols. Of 1,100 species previously examined by Carr et al. (1985), about 100 had polyphenol yields of $150 \mathrm{~g} / \mathrm{kg}$, while only $11 \mathrm{had}$ yields greater than $199 \mathrm{~g} / \mathrm{kg}$. Species yielding substantial amounts of both oil and polyphenol are rare, and are generally trees and shrubs, particularly evergreens (Carr et al., 1986).

\section{Hydrocarbon}

The general term hydrocarbon includes such chemicals as isoprene polymers, waxes, and terpenoids. Most plants identified as producing natural rubber contain less than $10 \mathrm{~g} / \mathrm{kg}$, dry weight basis, but the rubber generally is too low in molecular weight for conventional mixing and processing (Swanson et al., 1979). Low molecular weight natural rubber would be of interest as a plasticizing additive (processing aid) to rubber mixes, for liquid rubber processing methods, for making cements (adhesives), and if low enough in cost as hydrocarbon feedstocks (Buchanan et al., 1980).

Twenty-eight taxa of Helianthus collected throughout the USA and grown in a field nursery at Bushland, Texas, USA, were evaluated for yield of hydrocarbons in aboveground biomass (Seiler et al., 1991). Plant materials were analyzed using solvent extractable fractions referred to as hydrocarbons. Hydrocarbons were examined for the presence of rubber, gutta-percha, and waxes.

Yields of hydrocarbons were at least $6 \mathrm{~g} / \mathrm{kg}$ in 12 of the sunflower species. The lowest yields, $<1 \mathrm{~g} / \mathrm{kg}$, were found in $H$. argophyllus, $H$. debilis subsp. silvestris, $H$. petiolaris subsp. petiolaris, and $H$. pumilus. The first three species are annual, and the last perennial. The highest hydrocarbon yield was found in perennial $H$. salicifolius with $16 \mathrm{~g} / \mathrm{kg}$. With few exceptions, yields of hydrocarbon have been low, <20 $\mathrm{g} / \mathrm{kg}$ for over 1,000 species collected from various regions of the USA (Carr, 1985; Roth et al., 1982).

\section{Rubber}

The profitable production of natural rubber from cultivated domestic plants is of considerable interest to agriculturalists to ensure an uninterrupted supply of this critical raw material. There have been scattered reports in the literature about the presence of rubber in sunflower. Natural rubber from guayule is prominent among 
plant products intended for partial replacement of petrochemicals (Lopez et al., 1978). General screening programs have discovered that members of the Compositae family other than guayule (Parthenium argentatum), are capable of producing rubber. A prominent rubber-producing member of this family is wild Helianthus (Stipanovic et al., 1980; 1982).

Earlier surveys of plant families reported the occurrence of rubber in four species of sunflower: H. tuberosus, H. divaricatus (Minshall, 1957), H. atrorubens (Mitchell et al., 1942), and H. annuus (Bruehrer and Benson, 1945; Minshall, 1957). After examining 206 plant species (two of which were Helianthus species) growing in the central USA, Swanson et al. (1979) reported that the rubber in $H$. hirsutus had an average molecular weight and polydispersity factor that could produce a potentially useful rubber.

Carbon-13 nuclear magnetic resonance $\left({ }^{13} \mathrm{C} N M R\right)$ was used to detect natural rubber in extracts from wild and domesticated sunflower (Stipanovic et al., 1980). The rubber content of 23 wild species, two commercial hybrids, and one wild hybrid was determined by benzene extraction. Two wild species, $H$. agrestis and $H$. occidentalis, contained $16.6 \mathrm{~g} / \mathrm{kg}$ rubber in their foliar parts, while $H$. argophyllus contained $11.4 \mathrm{~g} / \mathrm{kg}$. A closely related species to Helianthus, Tithonia rotundifolia (Mexican sunflower) had over $20 \mathrm{~g} / \mathrm{kg}$ of a lower molecular weight rubber.

The rubber content of air-dried leaves of 31 wild species of sunflower was determined by a gravimetric method (Stipanovic et al., 1982). The species with a rubber content $>9.3 \mathrm{~g} / \mathrm{kg}$ were further analyzed by ${ }^{13} \mathrm{C}$ NMR spectroscopy. The rubber concentration in leaf extracts of $H$. radula was $19.3 \mathrm{~g} / \mathrm{kg}, 17.9 \mathrm{~g} / \mathrm{kg}$ in $H$. californicus, $19.3 \mathrm{~g} / \mathrm{kg}$ in $H$. resinosus, and $14.5 \mathrm{~g} / \mathrm{kg}$ in $H$. annuus. All species with the highest rubber content contained $>92 \%$ pure rubber. The benzene extract from many species was contaminated by high molecular weight straight-chain hydrocarbons. Little or no rubber was found in the benzene extract from stems of the wild sunflower examined, in contrast to guayule.

Earlier reports for cultivated sunflower hybrids " 894 " and "896" had foliar rubber contents of 4.9 and $7.4 \mathrm{~g} / \mathrm{kg}$, respectively (Stipanovic et al., 1980). Since all cultivated sunflower has been derived from wild $H$. annuus, it is especially noteworthy that wild $H$. annuus collected form Hinton, Oklahoma, had a rubber content of 14.5 $\mathrm{g} / \mathrm{kg}$. Brueher and Benson (1945) reported a rubber content of $5.5 \mathrm{~g} / \mathrm{kg}$ from wild $H$. annuus collected from Tucson, Arizona, while Minshall (1957) reported that wild $H$. annuus plants from Ontario, Canada, contained $2.6 \mathrm{~g} / \mathrm{kg}$. The reasons for these differences are uncertain and will require additional study with environmental effects highly possible, but hopefully the differences are due to the genetic variability within the species. There appears to be a high potential for increasing rubber content of cultivated sunflower. In view of the current interest in a domestic source of natural rubber, the potential of sunflower deserves additional study.

Mature aboveground plants of twenty-eight taxa of Helianthus (5 annual and 23 perennial) were analyzed for rubber and gutta-percha (Seiler et al., 1991). Rubber 
and gutta-percha compounds were further analyzed for weight-average molecular weight (Mwavg) and molecular weight distribution (MWD). Molecular weight distribution was determined by dividing the Mwavg by the Mn (number average molecular weight) (Swanson et al., 1979). Natural rubber was present in 13 species of wild sunflower. Helianthus maximiliani had the lowest Mwavg $2.98 \times 10^{4}$, while H. laevigatus had the highest, $7.33 \times 10^{4}$. Swanson et al. (1979) reported that $H$. hirsutus contains natural rubber with a molecular weight of $2.79 \times 10^{5}$, which indicates potential as a source of natural rubber. As for most plants, the values of the MWs are low compared with rubber from guayule with $1.28 \times 10^{6}$, and Para (Hevea brasiliensis) rubber with $1.31 \times 10^{6}$ (Swanson et al., 1979). However, low molecular weight rubbers may have potential as plasticizing additives in commercial processing of high molecular weight natural and synthetic polyisoprenes and as hydrocarbon feedstocks, replacing petroleum (Buchanan et al., 1980). If molecular weights greater than $2.0 \times 10^{4}$ can be utilized, the sunflower could become a source for both phytochemicals and rubber (Adams and Seiler, 1984).

Polydispersity characteristics (mixing and blending) of rubbers improve with increases in their MWD. Molecular weight distributions for wild sunflower varied from 2.14 for $H$. resinosus to 3.10 for $H$. laevigatus (Seiler et al., 1991). Most MWDs are within the range of those of commercial rubbers (Swanson et al., 1979). Swanson et al. (1979) reported that $H$. hirsutus contains natural rubber with a MWD of 3.1, which indicates its potential as a source of natural rubber.

Adams and Seiler (1984) examined the interrelationships among phytochemicals (cyclohexane extracts, rubber, methanol extractables, and proteins) from 39 taxa of Helianthus using principal component analysis. The correlation between cyclohexane extractables and rubber yield was only $r=0.26$. This was in spite of the intrinsic correlation since rubber is a subset of the cyclohexane extractables. The cyclohexane yield was also positively correlated with protein yield $(r=0.25)$ and essentially uncorrelated with methanol extract yield $(r=0.06)$. The rubber had a small correlation with the cyclohexane extract yield, essentially none with the methanol extract yield $(r=0.06)$ and a small negative correlation with protein yield. The methanol extract had a small correlation with protein yield $(r=0.28)$. It was concluded that in this study, there are not large correlations among any of the four variables, and selection and breeding to maximize more than one of these variables appear to be promising. However, additional samples will be needed from the population level to address this question.

\section{Seed protein}

The wild sunflower species may have potential to increase the protein concentration of achenes of the cultivated sunflower (Laferriere, 1986). Protein concentration of achenes is of interest for human or livestock consumption, but also is related to the production of the oil concentration in the achenes. Commercial sunflower meal has a protein concentration of approximately $440 \mathrm{~g} / \mathrm{kg}$ (dehulled) and 
$280 \mathrm{~g} / \mathrm{kg}$ (whole achene) (Doty, 1978). Protein concentrations ranging from 290 to $350 \mathrm{~g} / \mathrm{kg}$ have been reported in a survey of 39 species of wild Helianthus (Pustovoit and Krasnokutskaya, 1975). The protein concentration in whole achenes of perennial $H$. nuttallii subsp. nuttallii was $348 \mathrm{~g} / \mathrm{kg}$, while protein averaged $180 \mathrm{~g} / \mathrm{kg}$ in wild $H$. annuus (Seiler, 1984b). In other wild Helianthus species (6 perennials and 19 annual accessions), whole achene protein concentration ranged from $137 \mathrm{~g} / \mathrm{kg}$ in $H$. neglectus to $305 \mathrm{~g} / \mathrm{kg}$ in $H$. porteri (Seiler, 1986b). The protein concentration of whole seeds of annual species appears in general to be lower than that of perennial species (Seiler, 1984b). Laferriere (1986) suggested that it is possible that the high protein concentration of achenes of wild species may be due to their smaller size.

Sufficient variability for protein concentration exists in achenes of wild Helianthus species to be useful in breeding programs with an objective to increase protein concentration. Selection for high protein usually results in lower oil concentration because of a negative correlation between the two traits. Breeding to improve protein concentration of sunflower kernels from about 240 to near $400 \mathrm{~g} / \mathrm{kg}$, while maintaining acceptable oil concentration, appears to be a realistic objective (Ivanov and Stoyanova, 1978).

Sunflower protein ingredients derived from dehulled kernels have been evaluated extensively for use in human food both in Europe and in the U.S. (Lusas, 1982). Sunflower flour and protein concentrates and isolates show promise and are being used to a limited extent in bakery products, infant formula, meat, and meat extenders. Sunflower meal develops a greenish color due to the high concentration of chlorogenic acid, and must be removed prior to use in developing products for human consumption.

In one study, sunflower species with high whole-plant protein concentration did not have high yields of hydrocarbons, rubber, or polar extractables (Adams and Seiler, 1984). The implication of this could be a relationship between protein and hydrocarbons yield. If whole plant protein can be selected for, higher or lower, then it may be possible to manipulate hydrocarbon yields. Knowledge of the protein concentration of whole plants of the wild species could potentially facilitate the use of the wild species as new sources of hydrocarbons.

\section{Whole plant protein}

Twenty-eight taxa of wild sunflower have been analyzed for whole-plant protein concentration. Protein concentration ranged from a low of $38 \mathrm{~g} / \mathrm{kg}$ in $\mathrm{H}$. tuberosus to a high of $134 \mathrm{~g} / \mathrm{kg}$ in $H$. ciliaris (Seiler et al., 1991). Cultivated sunflower, $H$. annuus, had a higher protein concentration of $204 \mathrm{~g} / \mathrm{kg}$. In another study, 39 taxa of wild sunflower were analyzed for protein concentration at maturity with several species having protein concentration greater than $160 \mathrm{~g} / \mathrm{kg}$ (Adams and Seiler, 1984). Helianthus grosseserratus had a protein concentration of $201 \mathrm{~g} / \mathrm{kg}, \mathrm{H}$. arizonensis of $184 \mathrm{~g} / \mathrm{kg}$, H. simulans of $181 \mathrm{~g} / \mathrm{kg}$, H. petiolaris subsp. fallax of $173 \mathrm{~g} /$ $\mathrm{kg}$, and $H$. neglectus of $162 \mathrm{~g} / \mathrm{kg}$. In general, plant protein concentrations were 
lower than those previously reported for wild sunflowers (Seiler, 1986b). The differences in protein levels could be due to the different sampling times, ratio of different plant parts, and nitrogen fertility. In a study of 26 perennial and one annual species of wild sunflower, protein concentration generally declined as plants matured, with leaves having higher protein concentration than stems (Seiler, 1984b; Seiler, 1986b).

Jerusalem artichoke (Helianthus tuberosus), a wild perennial species native to North America, is cultivated in many areas of the world. Protein concentration of tubers of 19 wild and cultivated genotypes was analyzed at three growth stages (Seiler, 1990). The genotype "Iowa 1" at the vegetative stage had the lowest protein of $61.8 \mathrm{~g} / \mathrm{kg}$ (dry matter), while the highest was reported in "Minnesota 1" at the fruiting stage with $129.8 \mathrm{~g} / \mathrm{kg}$ (dry matter). Previous reports of protein in Jerusalem artichoke tubers based on dry-matter basis ranged from 62 to $128.2 \mathrm{~g} / \mathrm{kg}$ at full maturity (Cockerell, 1918) and $65.3 \mathrm{~g} / \mathrm{kg}$ at late flowering (Kaldy et al., 1980). In general, protein concentration increased with increasing maturity. The lowest average protein concentration, $76.5 \mathrm{~g} / \mathrm{kg}$, was at the vegetative stage. Average protein concentration increased to a maximum of $104 \mathrm{~g} / \mathrm{kg}$ at fruiting. The higher concentration of protein may be due to translocation of nitrogen from stem and leaves to tubers later in the season. A previous study reported that nitrogen concentration in leaves and stems of Jerusalem artichoke increases until flowering, then decreases at fruiting (Seiler, 1984b). The average protein concentration of Jerusalem artichoke tubers is similar to other more popular root and tuber crops such as potato, raw turnip, and water chestnut (Watt and Merrill, 1963).

\section{OIL CONCENTRATION}

\section{Whole plant oil}

Interest in nonfood uses of renewable resources has increased in recent years. Vascular plants produce many compounds and secondary metabolites, one of which is oil. Oil concentrations of up to $37 \mathrm{~g} / \mathrm{kg}$ have been reported in whole plants of a wild perennial sunflower, Helianthus ciliaris (Seiler et al., 1991). The wild sunflower species contain plant oil concentrations that are moderate compared with 1,000 other plants species analyzed (Roth et al., 1982). Plant oil yields of $60 \mathrm{~g} /$ $\mathrm{kg}$ or greater have been found in only 30 species.

\section{Achene oil}

In wild sunflower species and cultivated sunflower, the achenes are the primary storage organ for oil. Populations of wild sunflower species possess considerable variability for most economic and agronomic characteristics, one of which is seed oil concentration. Seed oil concentration has been reported for most wild species (Fick et al., 1976; Dorrell and Whelan, 1978; Thompson et al., 1978, 1981; Seiler, 1985), which generally have lower oil concentration than cultivated sunflower. Annual $H$. anomalus has the highest oil concentration reported in a wild sunflower 
species with $460 \mathrm{~g} / \mathrm{kg}$ (Seiler and Brothers, 2003). Oil concentration of other wild species ranges from $402 \mathrm{~g} / \mathrm{kg}$ in $\mathrm{H}$. niveus subsp. canescens, $377 \mathrm{~g} / \mathrm{kg}$ in $\mathrm{H}$. petiolaris subsp. petiolaris, $374 \mathrm{~g} / \mathrm{kg}$ in $H$. niveus subsp. tephrodes, $343 \mathrm{~g} / \mathrm{kg}$ in $\mathrm{H}$. deserticola to $250 \mathrm{~g} / \mathrm{kg}$ in $H$. annuus (Thompson et al., 1981; Seiler, 1985). Perennial $H$. salicifolius had a concentration of $370 \mathrm{~g} / \mathrm{kg}$ (Seiler, 1985). Cultivated sunflower generally contains 450 to $470 \mathrm{~g} / \mathrm{kg}$ (Robertson et al., 1979).

If wild species are utilized as sources of genes for pest resistance, oil concentration of interspecific hybrids can be rapidly increased to an acceptable level by backcrossing to cultivated lines. Thus, the low oil concentration of the wild species does not appear to be a limiting factor in utilizing them for sunflower improvement.

Several reports have evaluated sunflower oil and its blends with diesel as a fuel (Morrison et al., 1995). It is estimated that if farmers in North Dakota, USA, devoted about $10 \%$ of their acreage to sunflower production for fuel, the total onfarm fuel requirement could be met (Hofman and Hauck, 1982).

\section{Fatty acid composition}

The oil that accumulates in the achenes of wild and cultivated sunflower is composed of triacylglycerols that exist in the liquid form at room temperature and have a low melting point. The fatty acid composition of the achene oil determines its end use suitability.

Sunflower oil is a source of fatty molecules that can be used as reagents for chemical modifications (Girardeau et al., 2000; Leyris et al., 2000). Sunflower oil also has excellent nutritional properties. It is practically free of significant toxic compounds and has a relatively high concentration of linoleic acid. This polyunsaturated fatty acid is an essential fatty acid (not synthesized by humans), and is the precursor of gamma-linolenic and arachidonic acids (Dorrell, 1978). Sunflower oil is used in the manufacture of lacquers, copolymers, polyester films, modified resins, and plasticizers when there is a price advantage to the manufacturer.

The high concentration of linoleic acid and very low concentration of linolenic acid means that despite the moderate iodine number of 125 to 140 , sunflower oil has good drying qualities without the yellowing associated with high-linolenic acid oils (Dorrell and Vick, 1997). It can also be used in the manufacture of soap (Suslov, 1968). Emulsifiers and surfactants from fats and oils are being used in formulating pesticides (Pryde and Rothfus, 1989). In addition, with the development of high-oleic sunflower hybrids, sunflower oil has become a more important feedstock for the oleo chemical industry, with the cosmetics industry a major user (Luhs and Friedt, 1994).

The critical starting point of modern high-oleic and mid-oleic NuSun ${ }^{\circledR}$ type of sunflower oil can be traced to the mutation breeding efforts at the All-Union Research Institute of Oil Crops of the Former Soviet Union (FSU) (Soldatov, 1976). The initial plant with $500 \mathrm{~g} / \mathrm{kg}$ oleic acid was identified in the $\mathrm{M}_{3}$ generation after 
treatment with a $5 \mathrm{~g} / \mathrm{kg}$ dimethylsulfate solution. Eventually, the high-oleic variety "Pervenets" which contained up to $800 \mathrm{~g} / \mathrm{kg}$ oleic fatty acid, was produced.

Recent emphasis on sunflower oil concentration and fatty acid composition has increased interest in using wild species in breeding programs, but the introgression of low oil concentration and quality from the wild species into cultivated sunflower is of concern. Linoleic and oleic fatty acids are two important quality characteristics of sunflower oil. Wild sunflower species contain considerable variability for these two unsaturated fatty acids (Knowles et al., 1970; Fernández-Martinez and Knowles, 1976; Dorrell and Whelan, 1978; Thompson et al., 1978; Seiler, 1982, 1983, 1984a, 1985, 1986a; DeHaro and Fernández-Martinez, 1991). Sunflower oil with a high concentration of linoleic acid ( $>70 \mathrm{~g} / \mathrm{kg}$ ) is preferred for the production of soft margarine. High average linoleic acid concentrations (720 g/ kg) have been reported in three wild annual species, $H$. porteri $(832 \mathrm{~g} / \mathrm{kg}), H$. debilis subsp. tardiflorus (776 g/kg) and H. exilis (=bolanderi) $(778 \mathrm{~g} / \mathrm{kg})$, and 11 perennial species (Seiler, 1992). Several species had one or more populations with linoleic acid concentrations above $720 \mathrm{~g} / \mathrm{kg}$ with a range for the genus from $370 \mathrm{~g} / \mathrm{kg}$ in one population of $H$. argophyllus to $832 \mathrm{~g} / \mathrm{kg}$ in $H$. porteri.

Oleic acid, another important unsaturated fatty acid, appears to be quite variable in wild sunflowers. Among annual species, H. argophyllus had an oleic concentration of $475 \mathrm{~g} / \mathrm{kg}, \mathrm{H}$. annuus $463 \mathrm{~g} / \mathrm{kg}, \mathrm{H}$. praecox subsp. runyonii $410 \mathrm{~g} / \mathrm{kg}$, and H. debilis subsp. cucumerifolius $401 \mathrm{~g} / \mathrm{kg}$. Among the perennials, H. atrorubens had $538 \mathrm{~g} / \mathrm{kg}, H$. hirsutus $468 \mathrm{~g} / \mathrm{kg}$, H. silphioides $457 \mathrm{~g} / \mathrm{kg}, H$. resinosus $448 \mathrm{~g} / \mathrm{kg}$, and $H$. arizonensis $411 \mathrm{~g} / \mathrm{kg}$ (Thompson et al., 1981; Seiler, 1985). The lowest oleic acid concentration of the wild perennial species was observed in $H$. porteri with $55 \mathrm{~g} / \mathrm{kg}$ and $H$. radula with $93 \mathrm{~g} / \mathrm{kg}$.

High concentrations of palmitic and stearic acid were achieved using the mutagens sodium azide, ethyl methanesulfate, and X-rays on mature seeds (Osorio et al., 1995). The resulting mutant lines were selected from single $M_{2}$ and $M_{3}$ seeds. The mutant line CAS-5 has $250 \mathrm{~g} / \mathrm{kg}$ palmitic, and CAS-3, CAS- 4 , and CAS- 8 contain high concentrations of stearic acid, 260, 110 , and $100 \mathrm{~g} / \mathrm{kg}$, respectively.

High palmitic acid concentration, up to $400 \mathrm{~g} / \mathrm{kg}$, was obtained using gammaray irradiation on dry seeds (Ivanov et al., 1988). Fernández-Martínez et al. (1997) X-rayed dry seeds of high-oleic line BSD-42-3, producing CAS-12, having $300 \mathrm{~g} / \mathrm{kg}$ palmitic acid, but at the expense of the oleic acid concentration which was reduced from 880 to $560 \mathrm{~g} / \mathrm{kg}$. Research on the utilization of high palmitic and the high stearic hybrids is in progress and is expected to have both food and industrial application (Fernández-Martínez, personal communication).

Reduced concentrations of saturated palmitic and stearic fatty acids have been observed in a population of wild $H$. annuus, which had a combined palmitic and stearic acid concentration of $58 \mathrm{~g} / \mathrm{kg}$ (Seiler, 1998). This is $50 \%$ lower than in oil of cultivated sunflower. A combined palmitic and stearic acid concentration of $65 \mathrm{~g} / \mathrm{kg}$ was observed in a wild perennial species, H. giganteus (Seiler, 1998). In selected 
populations of $H$. pauciflorus subsp. subrhomboideus, the combined stearic and palmitic acids are less than $60 \mathrm{~g} / \mathrm{kg}$ (Seiler, 1994). This compares to concentrations of 100 to $120 \mathrm{~g} / \mathrm{kg}$ in cultivated sunflower.

Several potential sources of oil and oil quality characteristics that could be useful in hybrid improvement have been identified in the wild sunflower species. The fatty acid concentrations in the wild are comparable to the cultivated sunflower and react similarly to different environmental conditions (Seiler, 1982, 1983, 1986a). Thus, utilization of the wild species for other characteristics (e.g., resistance genes) does not appear to have a detrimental effect on fatty acid concentrations of the crop. It should be possible to use mutation to alter the fatty acid synthesis in wild sunflower since the wild species appear to have similar fatty acid pathways (Seiler 1983, 1986a).

Oil concentration and fatty acid composition of wild and cultivated sunflower, especially oleic and linoleic fatty acids, vary greatly mainly as a response to environmental factors, especially temperature during seed development (Harris et al., 1978; Seiler, 1986a). High temperature during seed maturation increases high oleic acid concentration, and reduces linoleic acid concentration.

\section{CARBOHYDRATES - INULIN AND SUGARS}

\section{Fructans (Fructose and Glucose)}

Crops like Jerusalem artichoke (JA) that produce reasonable amounts of easily fermentable carbohydrates can be regarded as potential energy crops on the grounds that they are raw materials of bioethanol (Sachs et al., 1981). Because of that, there has been an increased interest in JA. Inulin, the carbohydrate reserve of the JA crop, is soluble in water and after hydrolytic breakdown the reducing sugars fructose and glucose are released. Ethanol can be obtained by fermentation of the acid-hydrolyzed extracts using classical yeast. When yeasts are combined with inulinase activity, no acid hydrolysis is required. Research and development activities on JA as an alternate crop have been carried out since the 1980s.

Fructans and/or fructose have been suggested as raw materials for industrial fermentation for the production of ethanol, acetone-butanol, 2,3-butanediol (Fuchs, 1992), ethanol and sorbitol (Duvniak et al., 1991), and for the production by catalytic conversion of hydroxyl-methyl furfural and levulinic acids (Fuchs, 1992), suitable as synthesis intermediates for the production of polymers, dyes, detergents, liquid crystals, and herbicides (Gandini, 1990).

Most of the industrial production of fructose is presently obtained from corn starch as a fructose-rich syrup (isoglucose) by an enzymatic hydrolysis process followed by glucose isomerization and subsequent fructose separation (D'Egidio et al., 1998). It would be obviously more efficient to obtain fructose directly from crops such as JA that can synthesize and accumulate large amounts of such sugar polymers. 
Jerusalem artichoke is cultivated mainly for use as green or ensilaged forage, as a cover crop in marginal areas and to produce sugars (especially fructose) and fructans (inulin), which are used as food or in various chemical, electronic and pharmaceutical applications (Baldini et al., 2004; Bosticco et al., 1989; Meijer and Mathijssen, 1991; Marchetti, 1993). Jerusalem artichoke produces fleshy tubers rich in inulin and related carbohydrates (Mazza, 1985). The tubers are receiving considerable attention, both as a source of sugar for alcohol production and for possible utilization as a fructose sweetener (Rawate and Hill, 1985). Environmental issues and depletion of natural resources favor their utilization for industrial purposes. Many researchers believe that in the future more agricultural feedstocks will be used for their special properties, since they are renewable resources, have better degradability and are more acceptable to consumers than synthetic products. Jerusalem artichoke is one of the most mentioned candidates for use as a raw material for industrial production of biological fructose and inulin (Baldini et al., 2004).

Jerusalem artichoke could be considered an alternate sugar crop which accumulates linear fructose polymers (fructans) in its roots, tubers, and stem. The fructans, and the fructose resulting from fructan hydrolysis, can be used in the food industry (e.g., as dietary fibers and low calorie sweeteners), and in addition also have several nonfood medical and industrial uses (Fuchs, 1993). Although fructans have some specific food and nonfood applications, JA has to compete with established high-yielding crops for the sweetener market. In JA tubers, optimal N level (60 kg/ha) produced sugar yields of $8.1 \mathrm{Mg} / \mathrm{ha}$, while sugarbeet (Beta vulgaris) had sugar yields of $11.5 \mathrm{Mg} / \mathrm{ha}$, and root chicory (Cichorium intybus) yielded $11.2 \mathrm{Mg}$ / ha (Schittenhelm, 1999). The fructose content of the tubers averaged $170 \mathrm{~g} / \mathrm{kg}$ at the optimum $\mathrm{N}$ level. Since the total fructose and glucose after enzymatic hydrolysis includes a certain amount of fructose and glucose which is not bound in the fructans, the mean degree of polymerization (fructan chain length) (DP) of the fructans can be estimated according to Klaushofer et al. (1987). The mean fructans DP for JA at the optimum $\mathrm{N}$ level was 7.9.

Storage organ dry weight at optimum N level yield was $11.5 \mathrm{Mg} / \mathrm{ha}$ (Schittenhelm, 1999). Meijer et al. (1993) attributed the comparatively low tuber yields of Jerusalem artichoke to the large portion of assimilates that are fixed in the structural stem matter at tuber harvest, formation and maintenance of the storage tissue needed for the temporary storage of fructans in the stem, and metabolic costs of relocation of fructans from the stem to the tubers. However, another explanation for the large yield gaps compared with other crops is that the JA crop improvement programs in the past had very limited goals and were only operative at irregular intervals. Private plant breeders have not been interested in JA because of inadequate markets and the ease of vegetative propagation of this healthy plant, which does not require farmers to buy certified seed.

In order to better understand the developmental physiology of JA and to identify potential breeding objectives, the temporal pattern of development and alloca- 
tion of dry matter in plants was studied by McLaurin et al. (1999). Jerusalem artichoke allocated the major portion of its dry matter into aboveground parts during the first half of the growing season. Approximately 16 weeks after planting, the pattern of allocation shifted dramatically with a near cessation in the acquisition of dry matter, and reallocation of existing dry matter from the aboveground organs into the tubers. By the $16^{\text {th }}$ week after planting, $85 \%$ of the total dry matter was in the aboveground parts, but declined to $28 \%$ by the $30^{\text {th }}$ week. Of the total dry matter, $92 \%$ was accrued during the first 16 weeks and only $8 \%$ thereafter. By the end of the season, tubers had a yield of 14.6 t/ha. Tuber yield could be potentially improved through lengthening the period of carbon fixation and by earlier tuber induction and development. Somda et al. (1999) indicated that the JA had a distinctive carbon and nutrient element storage strategy. One characteristic of the JA plant was a relatively constant $\mathrm{C}$ level in each plant part during the period of rapid tuber development, while the total dry matter and $\mathrm{C}$ content decreased in the vegetative structures concurrently with an increase in the clonal structures. The tubers, in contrast, continued to accumulate $\mathrm{C}$ until the final harvest. In general, elemental accumulation in the tubers occurred at the expense of the other vegetative organs and the accumulation patterns were related to the mobility of the particular element in the phloem. Such data can be used to implement fertilization programs and to develop breeding programs for large tubers with improved nutritional quality. Selection of lines with the appropriate temporary sink volume and/or a longer period of carbon nutrient element fixation could theoretically improve tuber yields.

In developing new Jerusalem artichoke genotypes suitable for stalk yield or early integral crop (stalks and tubers at flowering time) harvesting, the objective is the maximization of inulin and total sugar yield in the stem (with the production of a large amount of biomass) and clones with early tuberization and tuber filling (Baldini et al., 2004). The yield of dry matter of aboveground biomass is very important at the time of first harvest, when it represents a temporary storage organ and the crop can be utilized as a stalk and multiyear crop (Caserta and Cervigni, 1991). The highest stalk yield was observed in clone 70 with 24.0 t/ha. The potential of clones to be used as an "integral crop" is indicated by the total biomass yield at the time of the first harvest (at flowering). Among the clones studied, clone 69 had the highest yield, 42.2 t/ha (Baldini et al., 2004).

The fructose content, expressed as percentage of fresh weight, showed higher mean values in the tubers than in the stalks in all genotypes (Baldini et al., 2004). Among clones, "Violette de Rennes" had the highest fructose concentration in the stalks of $166 \mathrm{~g} / \mathrm{kg}$, while clone 69 gave the highest in the tubers with 233 and $229 \mathrm{~g} /$ $\mathrm{kg}$ in the first and last harvest, respectively. With the exception of clone 17 at the first harvest, the glucose content, like that of fructose, was significantly higher in the tuber than in the stalks. The glucose content at the last harvest significantly increased with respect to the first harvest. The content of this sugar, if compared with fructose content, was very low, ranging between $9.2 \mathrm{~g} / \mathrm{kg}$ in stalks to $37.3 \mathrm{~g} / \mathrm{kg}$ in tubers at harvest. The inulin content (as percentage of fresh weight) resembled 
the pattern of the fructose content, ranging between 7.7 and $25.4 \mathrm{~g} / \mathrm{kg}$, and generally the inulin content in the stalk was lower than that in tubers (Baldini et al., 2004). The yield of total sugars (fructose + glucose) and inulin per unit area ( $t / h a)$ was very similar. Considering JA as a raw material for the industrial production of total sugars and harvesting just the stalks at flowering time would produce an inulin yield of the tubers and stalks of 10.4 and 8.9 t/ha, respectively. The sugar amount produced by tubers harvested at the end of the growth cycle is higher than that obtained from the stalks of all genotypes studied, even if, from an economic point of view, the sugar yield in the following years is considered without the replanting costs.

The average inulin chain length (DP) was highest at flowering time in both stalks and tubers with a range of 7.5 to 11.2 in the genotypes studied, while at the final harvest of tubers it significantly decreased reaching values ranging from 4.8 to 6.7 (Baldini et al., 2004). Among the organs analyzed, the tubers at stalk harvest showed both the highest inulin content and the longest inulin chain, expressed as DP.

Monti et al. (2005) studied the influence of moisture on dry matter and fructan accumulation in Jerusalem artichoke. Favorable water conditions affected biomass partitioning increasing the aboveground biomass and delaying the tuber initiation. The fructans accumulated firstly in the stem and then in tubers as they are formed. Effects of water stress were especially remarkable in the early growth period. Afterwards, a possible acclimation to water stress stimulated a deeper root development, and reduced the negative effect of the severe water deficit. The crop's acclimation to water stress reduced the aboveground biomass substantially, and marginally modified the fructan accumulation until the final harvest. Moreover, the fructan chains were never affected by water regime. Thus irrigation did not appear to be worthwhile for increasing fructans in this study.

Jerusalem artichoke stalks are an intermediate storage tissue, temporarily storing sugars before translocation to the underground tubers where they are stored. The JA has evolved a reproductive strategy of initially storing dry matter largely within the aerial components of the plant, followed by recycling the dry matter into tubers (Incoll and Neales, 1970). Previous research has investigated the use of the stalks instead of the tubers (Caserta and Cervigni, 1991; Fernández et al., 2000; Baldini et al., 2004). The current dry matter allocation strategy has additional energy costs that must be expended; i.e., production of aerial storage sites, storage of the dry matter, production of secondary storage sites, and remobilization of the dry matter from the primary sites and then restorage of the dry matter in the tubers (McLaurin et al., 1999). The extra energy cost for translocation alone has been estimated to be at least 3 to 6 ATPs/mole or 4 to $8 \%$ of the stored carbohydrates when grown under relatively optimum conditions (Meijer and Mathijssen, 1991). No doubt the physiological specialty of temporary stem storage in JA is a limitation for fructan production. 
Curt et al. (2005) focused on the production of soluble carbohydrates in stalks of JA grown in Spain. Twelve clones of JA of different maturity were evaluated. Aerial biomass weight ranged from 53.3 to $158.1 \mathrm{~g} /$ plant dry matter, while tuber production ranged from 312.5 to $887.4 \mathrm{~g} /$ plant. Mid-season clones generally produced higher tuber yields than the early clones. Tuber total soluble carbohydrates (TSC) averaged $653 \mathrm{~g} / \mathrm{kg}$. The maximum value of $778 \mathrm{~g} / \mathrm{kg}$ was recorded in clone "VR", which also had higher tuber weight. Production of bioethanol from JA stalks can be estimated from TSC data (Curt et al., 2005). The values ranged from $178 \mathrm{~g}$ sugar/ plant to a maximum of $583.9 \mathrm{~g}$ sugar/plant. The production of bioethanol from JA stalks can be estimated from the TSC production by estimating $0.51 \mathrm{~g}$ ethanol/g sugar as the theoretical yield of the ethanolic fermentation and assuming $90 \%$ efficiency (Curt et al., 2005). For the most productive clone in TSC, the estimated potential production of bioethanol from stalks would be $108.6 \mathrm{~g}$ ethanol/plant maximum. For average stalk production of $158.8 \mathrm{~g} \mathrm{TSC} /$ plant, the estimated yield would be $72.9 \mathrm{~g}$ ethanol/plant.

Sachs et al. (1981) estimated the yield of fresh tubers of cultivar "Sunchoke" grown in California at $32.9 \mathrm{Mg} / \mathrm{ha}$, while the dry weight yield was $11.5 \mathrm{Mg} / \mathrm{ha}$, with $35 \%$ dry matter. They estimated that on a dry weight basis, $82 \%(9.4 \mathrm{Mg} / \mathrm{ha})$ of the dry weight was fermentable and that ethanol production could be computed based on the assumption that $6.4 \mathrm{~kg}$ of fermentable material will yield 3.8 liters of ethanol. Based on this, Sachs et al. (1981) estimated that JA tubers could produce 5,500 liters of ethanol/ha, approximately the same as for sweet sorghum (Sorghum bicolor) also grown in California.

Since inulin is the primary constituent of interest, increasing the percentage of inulin in the tubers would decrease harvest, transport, and processing costs, even though the total biomass yield per hectare may not necessarily increase (McLaurin et al., 1999). Typically, JA cultivars have tuber inulin contents of 150 to $200 \mathrm{~g} / \mathrm{kg}$ on a fresh weight basis (Bacon and Edelman, 1951; Yanovsky and Kingsbury, 1938). At a fresh weight tuber yield of $50 \mathrm{t} / \mathrm{ha}$ and $150 \mathrm{~g} / \mathrm{kg}$ inulin, the inulin yield would be $7.5 \mathrm{t} / \mathrm{ha}$. If the percent inulin on a fresh weight basis is increased from 150 to $200 \mathrm{~g} / \mathrm{kg}$, and the tuber yield is held constant, the total amount of materials that must be harvested, transported, and processed would be reduced by $12.5 \mathrm{t} / \mathrm{ha}$. In addition, increasing the percent inulin reduces the amount of processing residues for disposal (McLaurin et al., 1999).

The potential of JA for fructose production under prairie conditions in Manitoba, Canada, was studied by Chubey and Dorrell (1974). Tubers of eight strains were harvested on seven dates, beginning in September and continuing until midNovember, when the soil was frozen to a depth of approximately $15 \mathrm{~cm}$. Carbohydrate extracts were hydrolyzed and analyzed for total reducing sugars, fructose and glucose. A high tuber-yielding Russian strain had a mean reducing sugars content of $169 \mathrm{~g} / \mathrm{kg}$, of which $768 \mathrm{~g} / \mathrm{kg}$ was fructose and $135 \mathrm{~g} / \mathrm{kg}$ was glucose. One native Manitoba strain yielded $277 \mathrm{~g} / \mathrm{kg}$ reducing sugar with $753 \mathrm{~g} / \mathrm{kg}$ fructose and $149 \mathrm{~g} /$ 
$\mathrm{kg}$ glucose. The depolymerization of the polyfructosans results in the different polymer content according to harvest date (Schorr-Galindo and Guiraud, 1997). The fructose/glucose $(\mathrm{F} / \mathrm{G})$ ratio is an index of polymerization of the reducing sugars. Reducing sugar content and fructose/glucose ratio generally declined with later harvests, with fructose generally decreasing and glucose increasing. Schorr-Galindo and Guiraud (1997) observed a similar reduction in the F/G ratio from 11 to 3 during harvest periods of six JA cultivars grown in France.

Alteration of fructan production in other root crops has been reported. A recent example is the creation of fructan in sugarbeet through inserting a single gene from JA that encodes an enzyme which converts sucrose to fructans in sugarbeet (Sévenier et al., 1998).

\section{BIOMASS YIELD}

Jerusalem artichoke can be grown for both tubers and aboveground biomass, but maximum yield for both forage and tubers has not been simultaneously obtained. The cultivation of JA on marginal lands has focused attention on sugar accumulation in stalks and branches during the summer, when growth of the plants decreases due to lack of water. The possibility of exploiting the stalk instead of the tuber as a source of sugar would require JA cultivars characterized by welldeveloped stalks and low tuber yields (Caserta and Cervigni, 1991).

The use of the stalks of JA instead of tubers as raw material for sugar production is very promising in southern regions of Europe (Caserta and Cervigni, 1991). The sugars of stalks are polysaccharides of the fructan type, probably synthesized by fructosyltransferase enzymes (Edelman and Jefford, 1968), and induced by high sucrose concentration. In dry climates the stalks can gradually accumulate up to 270 to $300 \mathrm{~g} / \mathrm{kg}$. The tolerance of the JA to drought stress might be due to the ability of the species to modify the degree of polymerization of the fructans pool (Caserta and Cervigni, 1991).

Early studies reported tuber and forage yields of only 2.2 to $2.8 \mathrm{Mg} / \mathrm{ha}$ (Anderson and Kiesselbach, 1929). Dry matter biomass yields of 3.0 to $9.9 \mathrm{Mg} / \mathrm{ha}$, and tuber yields of 2.8 to $12.8 \mathrm{Mg} /$ ha have been obtained (Kosaric et al., 1984). Seiler (1993) reported forage yields of Jerusalem artichoke cultivars grown in Texas, and sampled at flowering ranged from 3.0 to $6.3 \mathrm{Mg} / \mathrm{ha}$, with the cultivated JA "Sunchoke" having the highest yield at $6.3 \mathrm{Mg} / \mathrm{ha}$. At maturity, the allocation of biomass for JA was $68 \%$ stems, $23 \%$ leaves, and $9 \%$ heads. Jerusalem artichoke cultivar "Vadim" had the highest mean tuber yield, 9.04 Mg/ha, at maturity. Seiler (1993) also reported the biomass yields of wild JA populations grown in Texas. The biomass yield ranged from $3.0 \mathrm{Mg} / \mathrm{ha}$ to a high of $4.2 \mathrm{Mg} / \mathrm{ha}$ in the population "Texas". The allocation of biomass for the various plant parts was $70.4 \%$ stems, $19.8 \%$ leaves, and $9.8 \%$ heads. The dry matter content $(\mathrm{g} / \mathrm{kg})$ of JA tubers did not change significantly with respect to the years, time of harvest and clones, ranging between 220 and $260 \mathrm{~g} / \mathrm{kg}$; in contrast the dry matter of the stalks increased significantly in 
all clones from flowering ( 233 to $260 \mathrm{~g} / \mathrm{kg}$ ) to the end of the crop cycle (340 to 410 g/kg) (Baldini et al., 2004).

Schittenhelm (1999) reported that the relatively poor yields of JA, compared with sugarbeet, agrees with previous reports from California (Sah et al., 1987), Germany (Thome and Kühbauch, 1987), Denmark (Zubr, 1989), and the Netherlands (Meijer et al., 1993). Aboveground dry matter yield of a JA cultivar grown in Germany under optimal $\mathrm{N}$ conditions was $5.01 \mathrm{Mg} /$ ha (Schittenhelm, 1999). Tuber yield was $11.1 \mathrm{Mg} / \mathrm{ha}$ under the same conditions. The aboveground dry weights responded to $\mathrm{N}$ fertilization. The $120 \mathrm{~kg} / \mathrm{ha} \mathrm{N}$ rate increased the yield $43 \% \mathrm{com}$ pared with the no nitrogen treatment, while the optimal $\mathrm{N}$ rate appeared to be approximately $60 \mathrm{~kg} / \mathrm{ha}$. In the absence of weed and water stress, JA sugar yields were $70 \%$ of those of sugarbeet. The weed control by JA has a commercial advantage over sugarbeet, which generally requires multiple herbicide applications. However, the costs saved on the herbicides do not compensate for the lower sugar yield of JA (Schittenhelm, 1999). Jerusalem artichoke generally attained maximum sugar yields at the highest level of $\mathrm{N}$ fertilization. The different $\mathrm{N}$ regimes inconsistently affected the fructan chain length.

Selection of the lines that maintain a high level of $\mathrm{C}$ fixation after the onset of tuberization, especially if coupled with earlier tuber development, could significantly improve final yield (McLaurin et al., 1999). The existence of programmed senescence may be detrimental because in early maturing lines/cultivars, the aerial parts actually die prior to the end of the normal growing season.

\section{CONCLUSIONS}

The desire for alternative sources of fuels, chemicals, feeds, and other materials has received increased attention in the past decades. Environmental issues and depletion of natural resources favor their utilization for industrial purposes. Wild sunflower species have the potential to contribute to these renewable resources. During the past three decades, the narrow genetic base of cultivated sunflower has been broadened by the infusion of genes from wild relatives, which have provided a continuous source of agronomic traits for crop improvement.

Several phytochemicals have been identified in the wild sunflower species that have potential as renewable resources. Wild sunflowers have moderate levels of both non-polar and polar compounds in their biomass. These include hydrocarbons and natural rubbers of lower molecular weights. Considerable variability has been reported in fatty acid composition of oil in achenes of the wild species. The wild sunflower species also have considerable variability for protein concentration in achene and aboveground biomass.

Many researchers believe that in the future more agricultural feedstocks will be used for their special properties, since they are renewable resources, have better degradability and are more acceptable to consumers than synthetic products. Jeru- 
salem artichoke is one of the most-mentioned candidates for use as a raw material for industrial production of biological fructose and inulin. The greatest potential of the wild sunflower species for industrial use is as a feedstock for bioethanol production. Crops such as JA produce reasonable amounts of easily fermentable carbohydrates, such as fructans, that make it a potential energy crop and an alternate source for producing petrochemicals. Jerusalem artichoke is unique in that both stalks and tubers can be used for bioethanol production. Unfortunately, maximum yield for both aboveground and tuber production can not be simultaneously obtained. However, the advantage of JA is that it is a perennial crop with biomass yields in the following years obtained by re-growth of shoots, thus avoiding tuber replanting. The choice of a perennial crop, on the other hand, restricts the farmer, especially now that the agricultural policies are continually changing and evolving.

The wild species hold promise as sources of phytochemicals and for future improvement of cultivated sunflower as a crop for industrial uses. Further research through selection and breeding will be needed to assess the potential use of wild species for industrial uses.

\section{REFERENCES}

Adams, R.P. and McChesney, J.D., 1982. Phytochemicals for liquid fuel and petrochemical substitutions: extraction and screening results. Econ. Bot. 37:207-215.

Adams, R.P. and Seiler, G.J., 1984. Whole-plant utilization of sunflowers. Biomass. 4:69-80.

Anderson, A. and Kiesselbach, T.A., 1929. Cultural tests of Jerusalem artichoke. J. Am. Soc. Agron. 21:1001-1006.

Bacon, J.S.D. and Edelman, J., 1951. The carbohydrates of the Jerusalem artichoke and other Compositae. Biochem. J. 48:114-128.

Baldini, M., Danuso, F., Turi, M. and Vannozzi, G.P., 2004. Evaluation of new clones of Jerusalem artichoke (Helianthus tuberosus) for inulin and sugar yield from stalks and tubers. Ind. Crops. Prod. 19:25-40.

Bosticco, A., Tartari, E. and Benati, G., 1989. The Jerusalem artichoke (Helianthus tuberosus L.) as animal feeding and its importance for depressed areas. Agric. Med. 199:98-103.

Bruehrer, T.F. and Benson, L., 1945. Rubber content and native plants of the southwest desert. Arizona Agric. Exp. Stat. Tech. Bull. No. 108.

Buchanan, R.A., Otey, F.H. and Bagby, M.O., 1980. Botanochemicals. In: Recent Advances in Phytochemistry. Swain, T., and Kleinman, R. (eds.). Plenum Pub. Corp., New York. 14:122.

Carr, M.E., 1985. Plant species evaluated for new crop potential. Econ. Bot. 39:336-345.

Carr, M.E. and Bagby. M.O., 1987. Tennessee plant species screened for renewable energy sources. Econ. Bot. 41:79-85

Carr, M.E., Mason, C.T. and Bagby, M.O., 1986. Renewable resources from Arizona trees and shrubs. Forest. Ecol. Managem. 16:155-167.

Carr, M.E., Phillips, B.S. and Bagby, M.O., 1985. Xerophytic species evaluated for renewable energy resources. Econ. Bot. 39:505-513.

Caserta, G. and Cervigni, T., 1991. The use of Jerusalem artichoke stalks for the production of fructose or ethanol. Biores. Technol. 35:247-250.

Chubey, B.B. and Dorrell, D.G., 1974. Jerusalem artichoke, a potential fructose crop of the prairies. Can. Inst. Food Sci. Technol. 7:98-100.

Cockerell, T.D.A., 1918. The girasole or Jerusalem artichoke, a neglected source of food. Sci. Monthly. 6:260-269.

Curt, M.D., Aguado, P.L., Sanz, M., Sánchez, G. and Fernández, J., 2005. On the use of the stalks of Helianthus tuberosus for bio-ethanol production. In: Pascual-Villalobos, M.J., 
Nakayama, F.S., Bailey, C.A., Correal, E. and Schloman, W.W.Jr., (eds.). Industrial Crops and Rural Development. Murcia, Spain. pp. 947-955.

D’Egidio, M.G., Cecchini, C., Cervigni, T., Donini, B. and Pignatelli. V., 1998. Production of fructose from cereal stems and polyannual cultures of Jerusalem artichoke. Ind. Crops. Prod. 7:113-119.

Davis, J.B., Kay, D.E. and Clark, V., 1983. Plants tolerant of arid or semiarid conditions with nonfood constituents of potential use. In: Report of the Tropical Products Inst. G 150. Tropical Products Inst., London. pp. 1-172.

DeHaro, A. and Fernández-Martinez, J., 1991. Evaluation of wild sunflower (Helianthus) species for high content and stability of linoleic acid in the seed oil. J. Agric. Sci. 116:359367.

Dorrell, D.G., 1978. Processing and utilization of oilseed sunflower. In: Carter, J.F. (ed.). Sunflower Science and Technology. Crop Science Society of America, Madison, WI., USA. pp. 407-436.

Dorrell, D.G. and Vick, B.A., 1997. Properties and processing of oilseed sunflower. In: Schneiter, A.A. (ed.). Sunflower Technology and Production. Crop Science Society of America, Madison, WI., USA. pp. 709-745.

Dorrell, D.G. and Whelan, E.D.P., 1978. Chemical and morphological characteristics of seeds of some sunflower species. Crop Sci. 18:969-971.

Doty, H.O. 1978. Future of sunflower as an economic crop in North America and the world. In: Carter, J.F. (ed.). Sunflower Science and Technology. CSSA, ASA, SSSA. Monog. 19. Madison, WI., USA. pp. 457-488.

Duvnjak, Z., Turcotte, G. and Duan, Z.D., 1991. Production of sorbitol and ethanol from Jerusalem artichoke by Saccharomyces cerevisiae ATCC36859. Appl. Microbiol. Biotechnol. 35:711-715.

Edelman, J. and Jefford, T.G., 1968. The mechanism of fructosan metabolism in higher plants as exemplified in Helianthus tuberosus L. New Phytol. 67:517-531.

Fernández-Martínez, J. and Knowles, P.F., 1976. Variability in fatty acid composition of the seed oil of Helianthus species. In: Proc. $7^{\text {th }}$ Int. Sunflower Conf., Krasnodar, USSR. 27 June-3 July. Int. Sunflower Assoc., Toowoomba, Queensland, Australia. pp. 401-409.

Fernández, J., Curt, M.D. and Martínez, M., 2000. Balance between stalk sugar and tuber sugar production of Jerusalem artichoke (Helianthus tuberosus L.). In: Kyritsis, Beenackers, Helm, Grassi and Chiaramonti (eds.). Proc. $1^{\text {st }}$ World Conf. Biomass for Energy and Industry. Vol II. James and James Pub. pp.1885-1888.

Fernández-Martínez, J., Mancha, M., Osorio, J. and Garces, R., 1997. Sunflower mutant containing high levels of palmitic acid in a high oleic background. Euphytica. 97:113-116.

Fick, G.N., Zimmer, D.E. and Thompson, T.E., 1976. Wild species of Helianthus as a source of variability in sunflower breeding. In: Proc. Sunflower Res. Workshop, Bismarck, ND. 12-13 January. National Sunflower Assoc., Bismarck, ND. pp. 4-5.

Fuchs, A., 1992. Utilization of inulin. Internal Report, Wageningen Agricultural University, The Netherlands.

Fuchs, A., 1993. Production and utilization of inulin II. Utilization of inulin. In: Michio, S. and Chatterton, N.J. (eds.). Science and Technology of Fructans. CRC Press, Boca Raton, FL. pp. 319-352.

Gandini, A., 1990. Polymers and oligomers containing furan rings. Agri. Synthetic Polymers. pp. $195-208$

Girardeau, S., Vaca-Garcis, C., Aburto-Anel, J., Alric, I. and Borredon, M.E., 2000. Hydrophobation of polysaccharides with sunflower oil and its derivatives. In: Proc. $15^{\text {th }}$ International Sunflower Conference, Toulouse, France. 12-15 June, 2000. Int. Sunflower Assoc., Paris, France. pp. B73-B76.

Harris, H.C., McWilliam, J.R. and Mason, W.K., 1978. Influence of temperature on oil content and composition of sunflower seed. Aust. J. Agric. Res. 29:1203-1212.

Hofman, V.L. and Hauck, D.D., 1982. Demonstrating the extraction and use of sunoil. ASAE Paper 82-3609. ASAE, St. Joseph, MO, USA.

Incoll, L.D. and Neales, T.F., 1970. The stem as a temporary sink before tuberization in Helianthus tuberosus L. J. Exp. Bot. 221:469-476.

Ivanov, P. and Stoyanova, Y., 1978. Results from sunflower breeding directed to obtaining gene materials of high protein content in the kernel. In: Proc. $8^{\text {th }}$ Int. Sunflower Conf., Minneapolis, MN, USA. 23 -27 July. Int. Sunflower Assoc., Paris, France. pp. 441-448. 
Ivanov, P., Petakov, D., Nikolova, V. and Pentchev, E., 1988. Sunflower breeding for high palmitic acid content in the oil. In: Proc. $12^{\text {th }}$ Int. Sunflower Conf., Novi Sad, Yugoslavia. 25-29 July. Int. Sunflower Assoc., Paris, France. pp. 463-465.

Kaldy, K.S., Johnston, A. and D.B. Wilson. 1980. Nutritive value of Indian bread-root, squawroot, and Jerusalem artichoke. Econ. Bot. 34:352-357.

Klaushofer, H.B., Abraham, B., Liebhard, P. and Bucnik, P., 1987. Results of an investigation of nine Jerusalem artichoke cultivars from autumn and spring harvest 1985/1986. (In German). Die Branntweinwirtschaft. 127: 2-6.

Knowles, P.K. and Lessman, K.J., 1984. Development of new crops: need, procedures, strategies and options. In: Council for Agricultural Science and Technology (CAST) Report No. 102, Ames, IA. pp. 1-30.

Knowles, P.K., Temple, S.R. and Stolp, F., 1970. Variability in the fatty acid composition of sunflower seed oil. In: Proc. $4^{\text {th }}$ Int. Sunflower Conf., Memphis, TN. 23-25 June. Int. Sunflower Assoc., Toowoomba, Queensland, Australia. pp. 215-218.

Kosaric, N., Cosentino, G.P., Wieczorek, A. and Duvnjak, Z., 1984. The Jerusalem artichoke as an agricultural crop. Biomass. 5: 1-36.

Laferriere, J.E., 1986. Interspecific hybridization in sunflowers: an illustration of the importance of wild genetic resources in plant breeding. Outlook Agric. 15:104-109.

Leyris, J., Silvestre, F. and Rigal, L., 2000. Proteins of sunflower in aqueous solutions, rheology, and adhesive properties. In: Proc. $15^{\text {th }}$ International Sunflower Conference, Toulouse, France, 12-15 June, 2000. pp. B77-B83.

Lopez, E.C., Camacho, E.N. and Garcia, R.M., 1978. Guayule-Reencuentro en al Desierto. In: Proc. $2^{\text {nd }}$ Int. Conf. on Guayule, Saltillo, México. pp. 375-410.

Lusas, E.W., 1982. Sunflower meals and food proteins. In: The Sunflower. Adams, J. (ed.). National Sunflower Association, Bismarck, ND, USA. pp. 25-36.

Luhs, W. and Friedt, W., 1994. Non-food uses of vegetable oils and fatty acids. In: Murphy, D.J. (ed.). Designer Oil Crops: Breeding, Processing, and Biotechnology. VCH Press, NY. pp. 73-130.

Marchetti, G., 1993. Inulin e fruttani. Ind. Alimentari. 32:945-949.

Mazza, G., 1985. Distribution of sugars, dry matter, and protein in Jerusalem artichoke tubers. Can. Inst. Food Sci. Technol. 18:263-265.

McLaurin, W.J., Somda, Z.C. and Kays, S.J., 1999. Jerusalem artichoke growth, development, and field storage. I. Numerical assessment of plant part development and dry matter acquisition and allocation. J. Plant Nutr. 22:1303-1313.

Meijer, W.J.M. and Mathijssen, E.W.J.M., 1991. The relation between flower initiation and sink strength of stems and tubers of Jerusalem artichoke. Neth. J. Agric. Sci. 39:123-135.

Meijer, W.J.M., Mathijssen, E.W.J.M. and Born, G.E.L., 1993. Crop characteristics and inulin production of Jerusalem artichoke and chicory. In: Fuchs, A. (ed.). Inulin and InulinContaining Crops. Studies in Plant Science. Vol. 3. Elsevier Sci. Publ., Amsterdam. pp. 29-38.

Minshall, W.H., 1957. Rubber and resin content of native and introduced plants of Canada. Can. Dept. Agric., Ottawa, Ontario.

Mitchell, J.H., Rice, M.A. and Roderick, D.B., 1942. Rubber analysis of plants of South Carolina. Science. 95:624-625.

Monti, A., Amaducci, M.T. and Venturi, G., 2005. Growth response, leaf gas exchange and fructans accumulation of Jerusalem artichoke (Helianthus tuberosus L.) as affected by different water regimes. Europ. J. Agronomy 23:136-145.

Morrison, W.H., Hamilton, R.J. and Kalu, C., 1995. Sunflower seed oil. In: Hamilton, R.J. (ed.). Developments in Oils and Fats. Chapman and Hall, London. pp. 132-152.

Osorio, J., Fernández-Martínez, J., Mancha, M. and Garces, R., 1995. Mutant sunflowers with high concentration of saturated fatty acids in the oil. Crop Sci. 35:739-742.

Pryde, E.H. and Rothfus, J.A., 1989. Industrial and nonfood uses of vegetable oils. In: Robbelen, G., Downey, R.K. and Ashri, A. (eds.). Oil Crops of the World: Their Breeding and Utilization. McGraw- Hill, NY., USA. pp. 87-117.

Pustovoit, G.V. and Krasnokutskaya, O.N., 1975. Protein content of sunflower meal. In: Immunitet S.-Kh. Rast. K. Bolesnyam, Vreditelyam, Moscow [Plant Breed. Abstr. 31, No. 152]. 1975.

Rawate, P.D. and Hill, R.M., 1985. Extraction of high-protein isolate from Jerusalem artichoke (Helianthus tuberosus) tops and evaluation of its nutrition potential. J. Agric. Food. Chem. 33:29-31. 
Robertson, J.A., Morrison, W.H. and Wilson, R.L., 1979. Effects of planting location and temperature on oil content and fatty acid composition of sunflower seeds. USDA, Agricultural Research Services Results. Southern Series No. 3, Washington, D.C.

Roth, W.B., Cull, I.M., Buchanan, R.A. and Bagby, M.O., 1982. Whole plants as renewable energy resources: checklist of 508 species analyzed for hydrocarbon, oil, polyphenol, and protein. Trans. Illinois State Acad. Sci. 75:217-231.

Sachs, R.M., Low, C.B., Vasavada, A., Sully, M.J., Williams, L.A. and Ziobro, G.C., 1981. Fuel alcohol from Jerusalem artichoke. California Agri. September-October. pp. 4-6.

Sah, R.N., Geng, S., Puri, Y.P. and Rubatzky, V.E., 1987. Evaluation of four crops for nitrogen utilization and carbohydrate yield. Fert. Res. 13:55-70.

Schilling, E.E. and Heiser, C.B., 1981. Infrageneric classification of Helianthus (Compositae). Taxon. 30:393-403.

Schittenhelm, S., 1999. Agronomic performance of root chicory, Jerusalem artichoke, and sugarbeet in stress and nonstress environment. Crop Sci. 39:1815-1823.

Schorr-Galindo, S. and Guiraud, J.P., 1997. Sugar potential of different Jerusalem artichoke cultivars according to harvest. Biores. Technol. 60:15-20.

Seiler, G.J. 1982. Variation in oil and oil quality of wild annual sunflower (Helianthus annuus L.) populations in a uniform environment. In: Proc. $10^{\text {th }}$ Int. Sunflower Conf., Surfer's Paradise, Australia. 14-18 March. Int. Sunflower Assoc., Toowoomba, Queensland, Australia. pp. 212-215.

Seiler, G.J., 1983. Effect of genotype, flowering date, and environment on oil content and oil quality of wild sunflower seed. Crop Sci. 23:1063-1068.

Seiler, G.J., 1984a. Variation in agronomic and morphological characteristics of several populations of wild annual sunflower (Helianthus annuus L.). Helia 7:29-32.

Seiler, G.J., 1984b. Protein and mineral concentration of selected wild sunflower species. Agron. J. 76:289-294.

Seiler, G.J., 1985. Evaluation of seeds of sunflower species for several chemical and morphological characteristics. Crop Sci. 25:183-187.

Seiler, G.J., 1986a. Analysis of the relationships of environmental factors with seed oil and fatty acid concentrations of wild annual sunflower. Field Crops Res. 15:57-72.

Seiler, G.J., 1986b. Forage quality of selected wild sunflower species. Agron. J. 78:1059-1064.

Seiler, G.J., 1990. Protein and mineral concentration in tubers of selected genotypes of wild and cultivated Jerusalem artichoke (Helianthus tuberosus, Asteraceae). Econ. Bot. 44:322-355.

Seiler, G.J., 1992. Utilization of wild sunflower species for the improvement of cultivated sunflower. Field Crops Res. 30:195-230.

Seiler, G.J., 1993. Forage and tuber yields and digestibility of selected wild and cultivated genotypes of Jerusalem artichoke. Agron. J. 85:29-33.

Seiler, G.J., 1994. Oil concentration and fatty acid composition of achenes of North American Helianthus (Asteraceae) species. Econ. Bot. 48:276-279.

Seiler, G.J., 1998. The potential use of wild Helianthus species for selection of low saturated fatty acids in sunflower oil. In: de Ron, A.M. (ed). International Symposium on Breeding of Protein and Oil Crops. EUCARPIA, Pontevedra, Spain. pp. 109-110.

Seiler, G.J. and Brothers, M.E., 2003. Exploration for wild Helianthus anomalus and $H$. deserticola in the desert southwest USA. In: Proc. $25^{\text {th }}$ Sunflower Research Workshop, Fargo, ND. 16-17 January. National Sunflower Assoc., Bismarck, ND. 2003. (Available at: http://www.sunflowernsa.com/research/research_workshop/documents /90.pdf).

Seiler, G.J. and Rieseberg, L.H., 1997. Systematics, origin, and germplasm resources of wild and domesticated sunflower. In: Schneiter, A.A. (ed.). Sunflower Technology and Production. Crop Science Society of America, Madison, WI., USA. pp. 21-65.

Seiler, G.J., Carr, M.E. and Bagby, M.O., 1991. Renewable resources from wild sunflowers (Helianthus spp., Asteraceae). Econ. Bot. 45:4-15.

Sévenier, R., Hall, R.D., van der Meer, I.M., Hakkert, H.J.C., van Tunen, A.J. and Koops, A.J., 1998. High level fructans accumulation in a transgenic sugarbeet. Nat. Biotechnol. $16: 843-846$

Soldatov, K.I., 1976. Chemical mutagenesis in sunflower breeding. In: Proc. $7^{\text {th }}$ Int. Sunflower Conf., Krasnodar, USSR. 27 June-3 July. Int. Sunflower Assoc., Paris, France. pp. 352357. 
Somda, Z.C., McLaurin, W.J. and Kays, S.J., 1999. Jerusalem artichoke growth, development, and field storage. II. Carbon and nutrient element allocation and redistribution. J. Plant Nutr. 22:1315-1334.

Stipanovic, R.D., O’Brien, D.H., Rogers, C.E. and Hanlon, K., 1980. Natural rubber from sunflower. J. Agric. Food Chem. 28:1322-1323.

Stipanovic, R.D., Seiler, G.J. and Rogers, C.E., 1982. Natural rubber from sunflower. 2. J. Agric. Food. Chem. 30:611-613.

Suslov, V.M., 1968. Economic significance of sunflowers in the USSR. Proc. $3^{\text {rd }}$ International Sunflower Conference, Crookston, MN., USA, 13-15 August, 1968. Int. Sunflower Assoc., Toowoomba, Queensland, Australia. pp. 1-11.

Swanson, C.L., Buchanan, R.A. and Otey, F.H., 1979. Molecular weights of natural rubbers from selected temperate zone plants. J. Appl. Polym. Sci. 23:743-748.

Thome, U. and Kühbauch, W., 1987. Alternatives for crop rotation? (In German). DLGMitteilungen 18:978-981.

Thompson, T.E., Rogers, C.E., Zimmerman, D.C., Huang, D.C., Whalen, E.D.P. and Miller, J.F., 1978. Evaluation of Helianthus species for disease resistance and oil content and quality. In: Proc. $8^{\text {th }}$ Int. Sunflower Conf., Minneapolis, MN. 23-27 July. Int. Sunflower Assoc., Toowoomba, Queensland, Australia. pp. 501-509.

Thompson, T.E., Zimmerman, D.C. and Rogers, C.E., 1981. Wild Helianthus as a genetic resource. Field Crops Res. 4:333-343.

Watt, B.K. and Merrill, A.L., 1963. Composition of foods. USDA. Agric. Handb. 8. U.S. Gov. Printing Office, Washington, DC.

Yanovsky, E. and Kingsbury, R.M., 1938. Analysis of some Indian food plants. J. Assoc. Off. Agric. Chem. 21:648-665.

Zubr, J., 1989. Jerusalem artichoke as a field crop in Northern Europe. In: Grassi, G., and Gosse, G. (eds.). EUR 11855-Topinambour (Jerusalem artichoke). Proc. EC Workshop, Madrid, Spain. 30 Sept-1 Oct. 1987. pp. 105-117.

\title{
POTENCIAL DE LAS ESPECIES SILVESTRES DE GIRASOL PARA EL USO INDUSTRIAL
}

\author{
RESUMEN
}

En los últimos diez años está creciendo la necesidad de las fuentes de combustible alternativas, químicos, forraje y otro material. Las especies silvestres de girasol poseen el potencial de utilizarse como fuente renovable. Durante las últimas tres décadas, la base genética estrecha de girasol cultivado, ha sido ampliada, incluyendo genes de sus parentescos silvestres, que garantizaban una permanente fuente de nuevas propiedades agronómicas para el mejoramiento de ese cultivo agricultor. El género Helianthus está compuesto por 51 especies y 19 subespecies, de las cuales 14 anuales y 37 perennes. Aunque en una especie silvestre, $H$. ciliaris, fue notada la concentración de aceite de $37 \mathrm{~g} / \mathrm{kg}$ a nivel de planta entera, la semilla queda el órgano primario de acumulación de aceite. El contenido de ácidos grasos en el aceite determina su utilizabilidad, para nutrición o el procesamiento industrial. Una significante variabilidad ha sido determinada en la composición de ácidos grasos en el aceite de las especies silvestres de girasol. Las especies silvestres también pueden ser fuente de otros productos naturales, de significado económico. La concentración de caucho natural de $19 \mathrm{~g} / \mathrm{kg}$ a nivel de la planta entera, fue notada en la especie silvestre perenne $H$. radula, con más de $92 \%$ de caucho puro. El rendimiento de polifenol de la biomasa del girasol silvestre es moderado, con el rendimiento de $139 \mathrm{~g} / \mathrm{kg}$ en la especie $H$. strumosus. El rendimiento de hidrocarburo de la biomasa del girasol silvestre es promedio, con el rendimiento máximo de $16 \mathrm{~g} / \mathrm{kg}$ en la especie $H$. salicifolius. El conte- 
nido de azúcar en los tallos y tubérculos de topinambura (H. tuberosus) se citaba como una potencial fuente para la producción de bioetanol. El rendimiento de inulina y azúcar del tallo de topinambura, se ha determinado a nivel de 10,4 y 8,0 t/ha, mientras que los tubérculos contenín 13,7 t/ha de inulina y 13.3 t/ha de fructosa. Topinambura también fue investigada en vista de la producción de biomasa. Se han notado los rendimientos desde 3,0 hasta 9,9 t/ha de la masa verde seca y 2,8 hasta 12,8 t/ha de tubérculos. Se necesitan investigaciones adicionales para evaluar el valor potencial de las especies silvestres de girasol para el uso industrial, y este potencial se realizaría a través de la selección.

\title{
POTENTIEL D'ESPÈCES SAUVAGES DE TOURNESOL POUR LES BESOINS DE L'INDUSTRIE
}

\author{
RÉSUMÉ
}

Le besoin de sources alternatives de carburants, de produits chimiques, de nourriture animale et d'autres matières a augmenté au cours des dix dernières années. Les espèces sauvages de tournesol pourraient servir de ressources renouvelables. La mince base génétique du tournesol de culture a été élargie au cours des trente dernières années par l'inclusion de gènes de parents sauvages qui ont été une source constante de nouvelles caractéristiques agronomiques améliorant cette culture. Le genre Helianthus se compose de 51 espèces et de 19 sous-espèces dont 14 sont annuelles et 37 vivaces. Bien qu'une concentration d'huile de $37 \mathrm{~g} / \mathrm{kg}$ ait été observée dans l'espèce sauvage, H. ciliaris, au niveau de la plante complète, les akènes restent l'organe principal d'accumulation d'huile. Le contenu d'acides gras dans l'huile détermine son utilité pour l'alimentation ou l'industrie. Une variété importante a été constatée dans le contenu des acides gras de l'huile d'espèces sauvages de tournesol. Les espèces sauvages peuvent elles aussi être une source d'autres produits naturels d'importance économique. Une concentration de gomme naturelle de $19 \mathrm{~g} / \mathrm{kg}$ au niveau de la plante complète a été observée dans l'espèce vivace $H$. radula avec plus de $92 \%$ de gomme pure. Le rendement de polyphénol de la biomasse du tournesol sauvage est moyen avec $139 \mathrm{~g} / \mathrm{kg}$ pour l'espèce $H$. strumosus. Le rendement en hydrocarbures pour la biomasse du tournesol sauvage est moyen pour la plupart des espèces, c'est le $H$. salicifolius qui a le rendement le plus élevé, $16 \mathrm{~g} / \mathrm{kg}$. Le contenu de sucre dans les tiges et les tubercules de l'artichaut de Jérusalem ( $H$. tuberosus) a été cité comme une source potentielle de production de bioéthanol. Le rendement d'insuline et de sucre de la tige du topinambour a été établi au niveau de 10,4 et 8,0 t/ha, tandis que les tubercules contenaient 13,7 t/ha d'insuline et 13,3 t/ha de fructose. Le topinambour a aussi été testé pour la production de biomasse. Des rendements de matière sèche de 3,0 à 9,9 t/ha et des rendements de tubercules de 2,8 à 12,8 t/ha ont été observés. Des recherches ultérieures seront nécessaires pour déterminer l'utilisation potentielle des espèces sauvages dans l'industrie ; ce potentiel se réaliserait par la sélection. 
